\title{
A CONTRIBUTION TO THE GEOLOGICAL STRUCTURE OF CHIOS ISLAND, EASTERN AEGEAN SEA
}

\author{
Tselepidis V. ${ }^{1}$ and Rondoyanni Th. ${ }^{2}$ \\ ${ }^{1}$ Institute of Geology and Mineral Exploration, Department of Geology and Geological Mapping, \\ vtselepidis@igme.gr \\ ${ }^{2}$ National Technical University of Athens, School of Mining and Metallurgical Engineering, \\ Department of Geological Science, rondo@central.ntua.gr
}

\begin{abstract}
The island of Chios, in the eastern Aegean Sea, is of great geological interest due to the outcrops of the oldest Paleozoic rocks of the Hellenides. Three main geological units of Paleozoic and Mesozoic age dominate, that have a tectonic relationship: the Autochthonous unit is overthrusted by the Parautochthonous unit, which in turn is overthrusted by the Allochthonous unit.

In this work, new geological and tectonic data concerning the Autochthonous unit and especially its part of the Paleozoic - Mesozoic transition are presented and evaluated. Due to the rare outcrops of this transition and the lack of sufficient palaeontological data, there are various and contradictory opinions concerning its normal or discordant character. Based on our field data and lithostratigraphic correlations, we can draw the following main results:

Considering the Autochthonous unit, the transition of the Paleozoic formations to the Mesozoic ones is characterized by an angular unconformity as well as by a basal conglomerate. In some places there is a tectonic contact between them, this of a thrust fault. The Lower Triassic formations of the Parautochthonous unit belong to the Autochthonous unit, since they present similar palaeogeographic conditions. Moreover, the presence of the "Hallstatt" limestones in the Autochthonous unit can be explained by their local deposition in lenticular form.
\end{abstract}

Key words: Chios Island, Autochthonous Unit, Parautochthonous Unit, Hallstatt facies, Nagos spring.

\section{Introduction}

As the Island of Chios, in the eastern Aegean Sea, has an important geological structure, several geological studies have been conducted there, referring predominantly to the stratigraphic evolution of the Paleozoic and Mesozoic formations. The tectonic structure of Chios is very complicated as a result of several pre-alpine and alpine tectonic phases (Ktenas, 1921; Besenecker, et al. 1968; Herget, 1968; Roth, 1968; Bender, 1970; Assereto et al., 1980; Papanikolaou and Sideris, 1983; Gaetani et al., 1992; Robertson and Pickett, 2000).

According to the geological map of Chios, on a 1:50.000 scale (Besenecker et al., 1971), the greatest part of the island is covered by an Autochthonous unit, the Lower one. It consists of a turbiditic succession including olistoliths of Silurian and Carboniferous rocks, lutites, vulcanites and tuffs of 


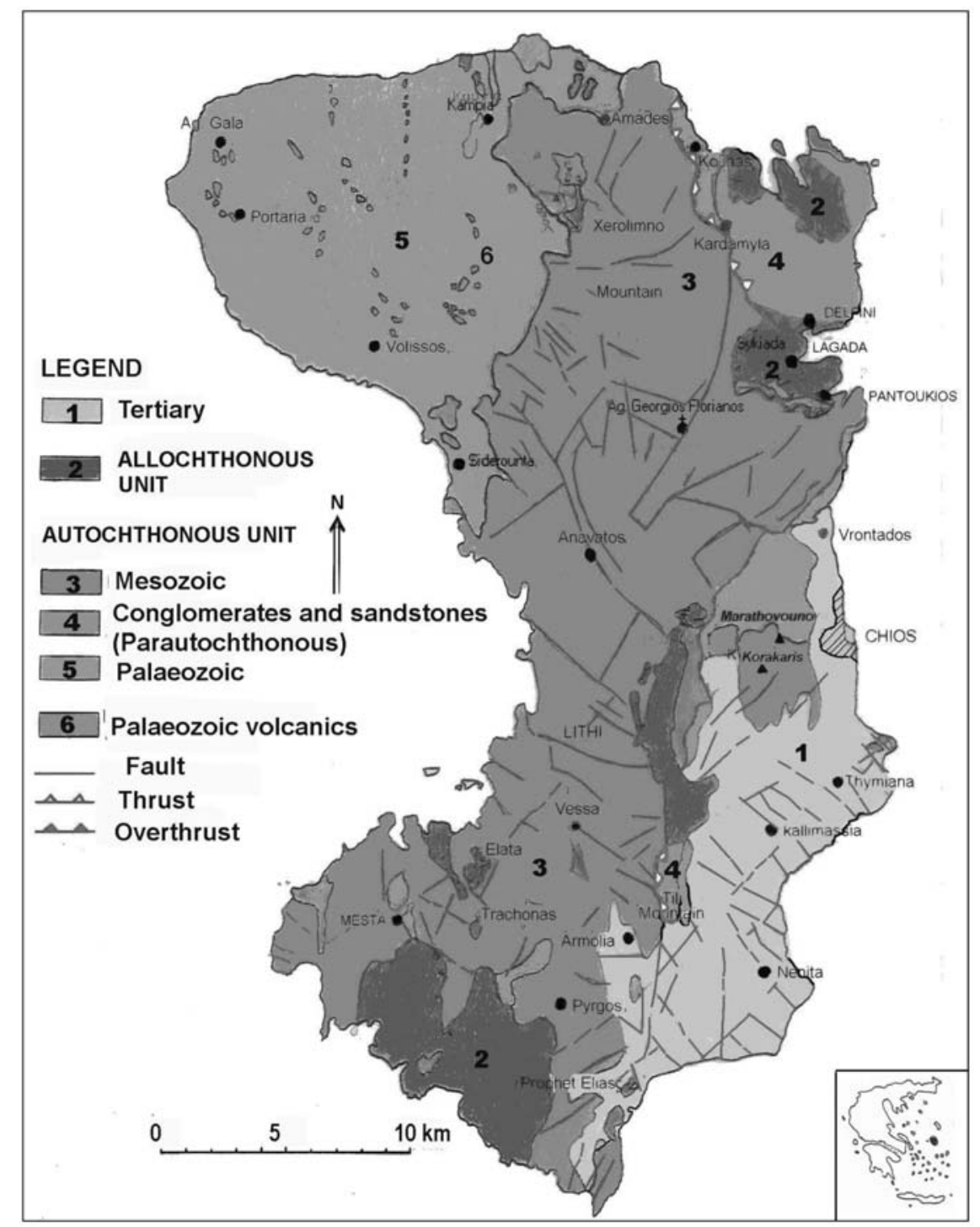

Fig. 1: Structural map of the island of Chios.

the Upper Devonian to Westfalian age, and of a Mesozoic carbonate succession, developed from the base of the Triassic to Lias (Fig. 1). Different tectonic models have been proposed as to the origin of the clastic, chaotic Palaeozoic unit, considered a wildflysch sequence and named Chios melange (Groves et al., 2003). Robertson and Pickett (2000) have interpreted it as a rift setting and a deposition on a deep marine basin. The transition of the Paleozoic formations to the Mesozoic ones is characterized by an angular unconformity as well as by a basal conglomerate.

The Autochthonous unit is overthrusted by the Upper unit (Allochthonous) consisting of a Pensylvanian to Upper Permian sequence, of red siltstones of undetermined age and of Liassic shallowwater carbonates (Kauffman, 1969; Zanchi et al., 2003). Between these two main units, the 


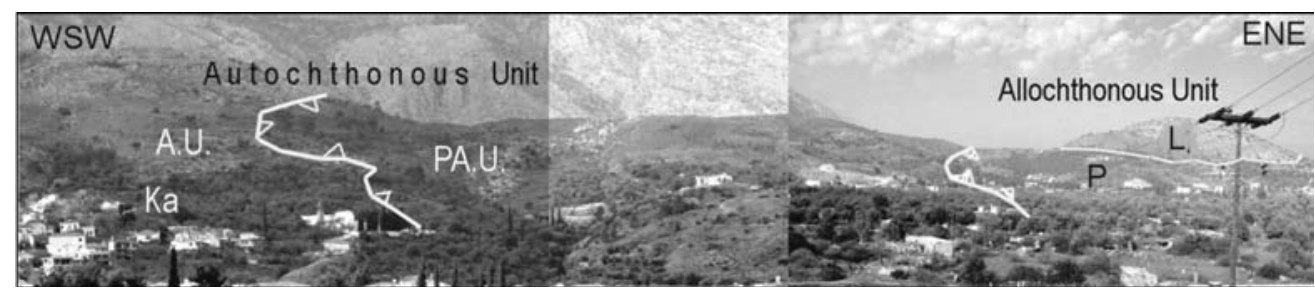

Fig. 2: View towards the North of the thrust sheets observed in north-eastern Chios (Ka-Kardamyla village, A.U.-Autochthonous Unit, PA.U.- Parautochthonous Unit, AU-Allochthonous Unit, P-Palaeozoic, L-Lias).

Intermediate unit (Parauthochthonous) cropping out mainly at the north-eastern part of the island (Fig. 2), consists of Upper Palaeozoic and intensively tectonised Liassic carbonate rocks. Due to the lack of sufficient palaeontological data, there are alternative interpretations concerning the origin of this Parauthochthonous unit, mainly based on correlative observations. Besenecker et al. (1968) consider that the Parauthochthonous unit constitutes a fragment of the substratum, carried over with the Allochthonous unit during its emplacement.

The south-eastern part of the island is covered by fluviolacustrine Upper Miocene - Lower Pliocene deposits, consisting of conglomerates, clays and limestones. Miocene and post-Miocene volcanic rocks of limited extension also crop out in different places on the island.

The aim of this paper is to present new data obtained on the Island of Chios, in view of reconsidering the relationship of the tectonostratigraphic units. The study focuses on the Palaeozoic-Mesozoic transition of the Autochthonous unit and the Mesozoic of the Parauthochthonous unit. The results of this work are of a preliminary character because no palaeontological evidence could be found in the collected samples, despite a systematic sampling undertaken. Although lithostratigraphic and tectonic data have led us to propose a different structural model, further research is needed to explain the complicated geological structure of Chios and to interpret the palaeogeographic regime of the broader area.

\section{The geological structure of the Autochthonous and Parau-tochthonous units}

The Autochthonous unit includes a Palaeozoic sequence uncomfortably overlain by Mesozoic carbonate formations, while transgression conglomerates have developed between them. The lower members of these Mesozoic carbonates show similar lithofacial evolution with the Parautochthonous unit's (Fig. 3). In ascending order, they both consist of:

(a) A basal conglomerate, alternating with coarse-grained sandstones, indication of the alpine transgression on the intensively tectonised Variscan substratum. This formation, constituting the Palaeozoic-Mesozoic boundary, is developed mainly at the northern part of the island, exhibiting its whole thickness in the area of Giossonas.

(b) Thin-bedded, multi-folded limestones of undetermined age, due to the lack of any palaeontological evidence. According to their lithostratigraphic position, a Skythian age could be attributed to them.

(c) The upwards continuity of the Mesozoic sequence differs from place to place. Massive limestones and dolomites of Anisian-Skythian age, dominating in both the Autochthonous and Parautochthonous units, are observed in the northern part of the island. Oolithic limestones are more abundant in the Autochthonous unit. In the southern part outcrop mainly red, micritic limestones of the "Hallstatt" facies and dolomites, dated Upper Scythian to Lower Anisian on the 


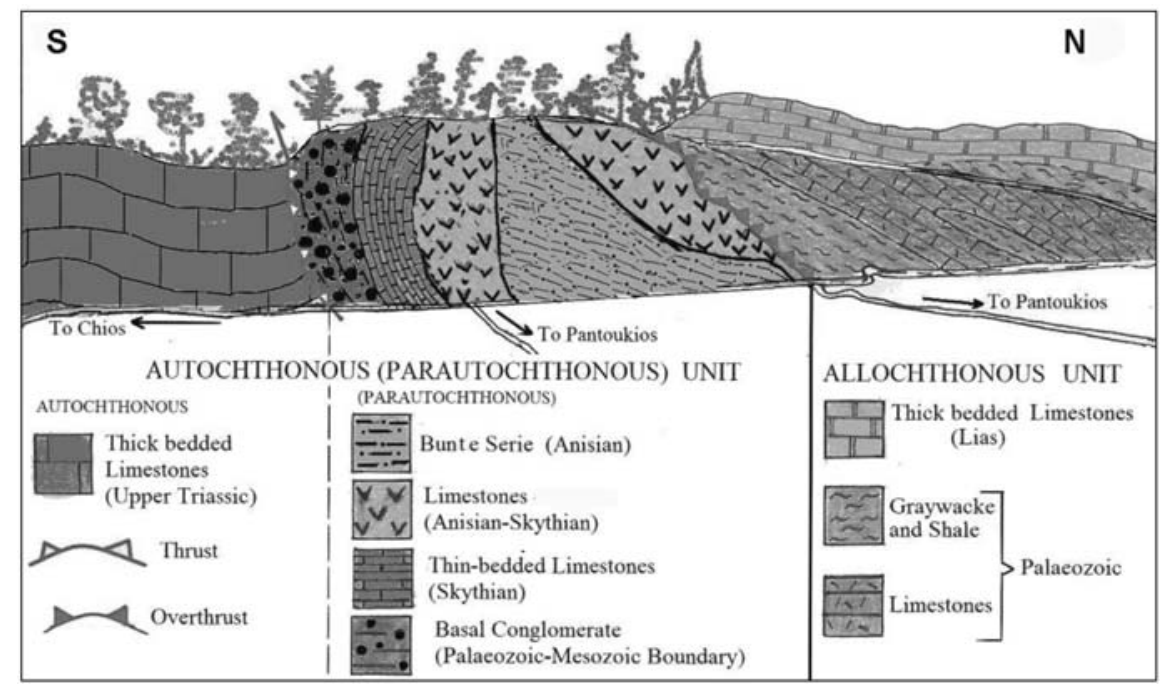

Fig. 3: Schematic geological section along the Vrontados-Pantoukios road (the locations are noted on Fig. 1).

basis of the ammonitic fauna. The characteristic "Hallstatt" limestones which can be easily recognised in the field, have not developed throughout the extent of the Mesozoic sequence and are absent in the northern part of the island.

(d) The "multi-colored sequence" (known as "Bunte Serie") of Anisian age, overlays the above described formations (Figs 4, a and b). It consists of alternating clastic sediments, cherts, radiolarites, limestones, marls, sandy marls, sandstones and conglomerates in the lower part and of well-bedded grey limestones, reddish marly limestones, marls and brecciated horizons in the upper part. According to the included conodonts, these formations are of Anisian age (Kauffman, 1969). The evolution of the Autochthonous Mesozoic sequence on the Autochthonous Palaeozoic substratum can be observed in the region of the mountain Korakaris (Fig. 4a). The Palaeozoic-Mesozoic contact is also observed in this part of the island, to the North of the village Vrontados (Fig. 5a). In some places, the "Bunte Serie" lay directly on the thin-bedded limestones (Fig. 5b), but there is a tectonic contact between them. Such an outcrop can be observed to the North-East of the village Kardamyla.

Although the lack of detailed palaeontological evidence does not allow definitive results concerning the stratigraphic comparison between Autochthonous and Parautochthonous units based on field observations, the lithostratigraphic evolution of these two units presents two differences only. The first is that the "Halstatt" limestones are present in the Autochthonous but not in the Parautochthonous unit. This difference can be explained if we take into account the sedimentation conditions of the "Hallstatt" facies in the environment of the continental shelf borders. This formation does not have a uniform development throughout its extension, because of its lenticular form; it "disappears" abruptly in the horizontal and vertical sense. It should be noted that in many places in the north-eastern part of Chios Island (e.g. in the area of the village Pantoukios along the coast), we can observe the development of the upper members of the Mesozoic carbonate sequence on the Palaeozoic substratum of both the Autochthonous and Parautochthonous units.

The second difference is that the formations of the Parautochthonous unit are intensively folded and 


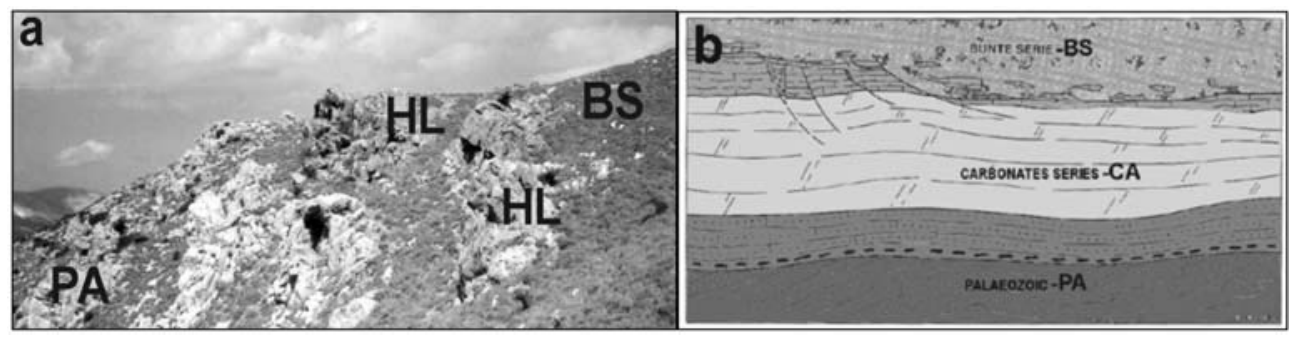

Fig. 4: (a) View of the Authochthonous Mesozoic carbonate series in the Korakaris region. (PA-Palaeozoic, HL-“Hallstatt" limestones, BS- "Bunte Serie") (b) Schematic representation of the same region after Geatani et al. (1992)
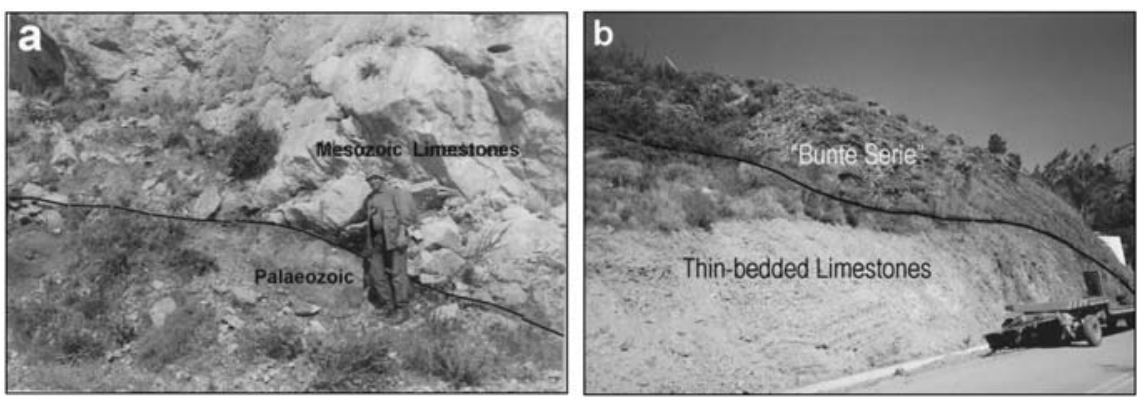

Fig. 5: (a) View of the contact of Authochthonous Palaeozoic with Mesozoic limestones, to the north of the village Vrontados. (b) View of the contact of thin-bedded limestones of the Autochthonous unit with the "Bunte Serie".

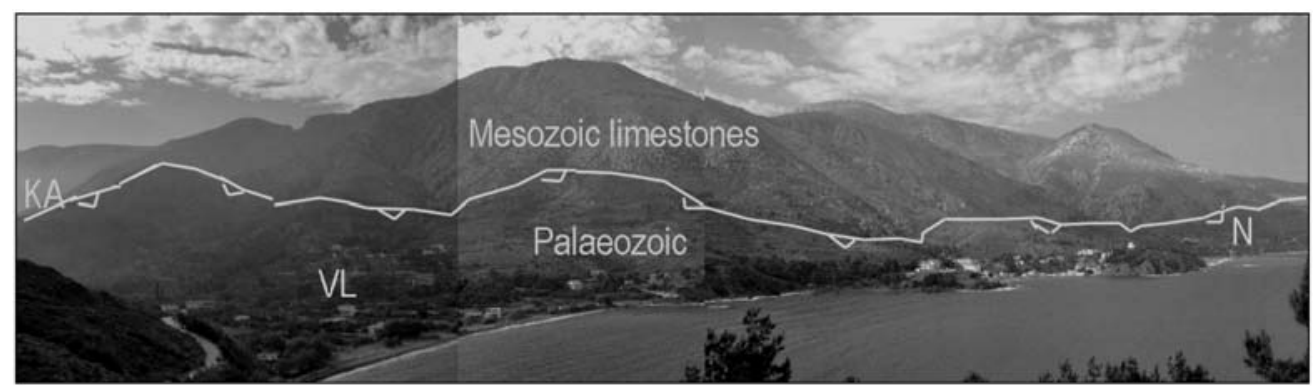

Fig. 6: View of the thrust of the Palaeozoic on the Mesozoic in NE Chios (KA-Kardamyla, VL-Vlychada, N-Nagos).

fractured. This happens systematically only in places where the Allochthonous unit overthrusts the Autochthonous one. Moreover, the Parautochthonous unit only crops out between the other two units and nowhere does it have an independent presence. This fact may also lead to the thought that it does not represent an individual unit deposited onto a different paleogeographic space, but corresponds to the base of the Mesozoic sequence of the Autochthonous unit, thrusted on the Upper Triassic formations of the same unit.

According to recent tectonic observations, the contact between the Palaeozoic and Mesozoic formations of the Autochthonous unit is represented by a thrust structure, observed in north-eastern Chios. This contact has been mapped in the broader area of Vlychada-Nagos, where clastic formations overlay on limestones and dolomites (Fig. 6). This thrust surface has a strike ranging from 


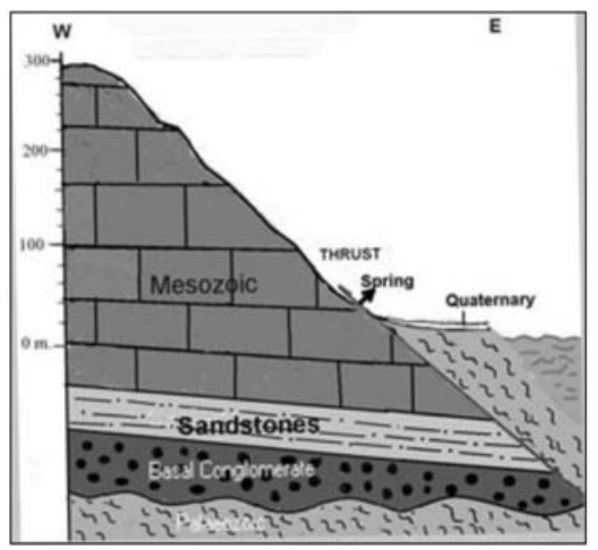

Fig. 7: Schematic geological cross section of the thrust structure at the Nagos spring area.
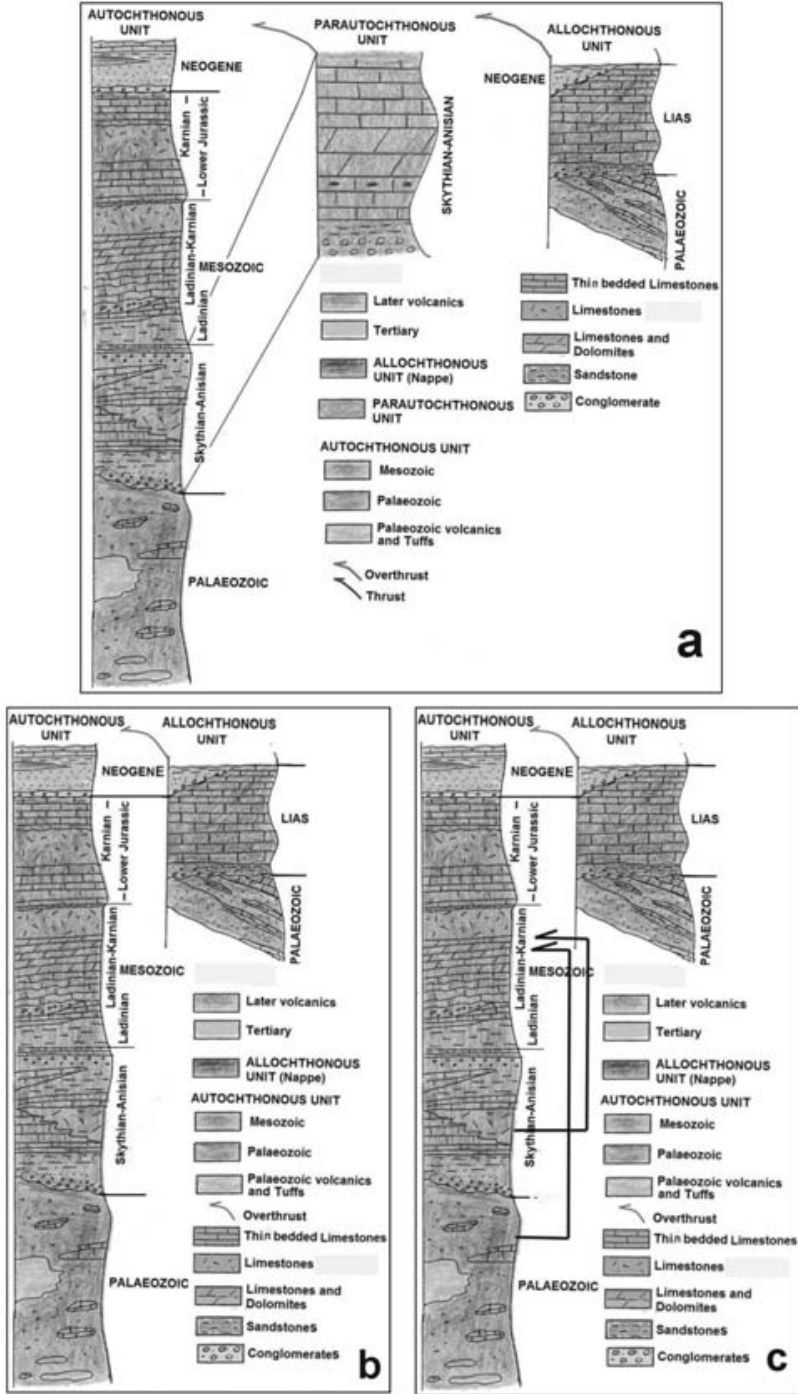

Fig. 8: Schematic lithostratigraphic columns of the Chios structural units (a) and the revised scheme according to the results of this work (b and c). 
$\mathrm{N} 5^{\circ} \mathrm{W}$ to $\mathrm{N} 5^{\circ} \mathrm{E}$ and a dip of $45^{\circ}$ to the East, while the tectonic striations observed in some places have a $22^{\circ}$ pitch to the North. This tectonic relationship is the origin of the Nagos overflow spring, expressed in the contact of the Palaeozoic and Mesozoic formations (Fig. 7). Geophysical research conducted for hydrogeological purposes by the Institute of Geology and Mineral Exploration of Athens, confirmed the presence of this thrust structure.

Finally, the massive limestones of the Autochthonous Mesozoic series are thrusted either by Palaeozoic clastic formations, or by the basal Mesozoic formations of the same series (Fig. 8c). Following the above data and rationale, a modified structural scheme is proposed for the island of Chios, according to which the Parautochthonous unit is not an individual unit (as in Fig. 8a) but is considered a part of the Autochthonous one (Fig. 8b).

\section{Conclusions}

According to recent structural observations carried out in Chios Island (more detailed in its northeastern part), a revised model is proposed for the geological structure. The Parautochthonous unit is not considered an individual unit but constitutes part of the Autochthonous one. Indeed, the geological formations of the Parautochthonous unit, such as the thin-bedded limestones and cherts, have their equivalents in the Autochthonous unit. Comparing these two units from a lithostratigraphic point of view, the major difference between them is the presence of the "Hallstatt" limestones in the Autochthonous unit. They crop out in the south-western part of the island while they are absent in the north-eastern part. Taking into account the sedimentation conditions of the "Hallstatt" facies in the environment of the continental shelf borders we can suppose that it has a lenticular form and for this reason a non uniform extension.

The fact that the two units present local lithofacial differentiations does not lead to the conclusion that they have a different palaeogeographic origin, as both are covered by the same formation, the "Bunte Serie". It should be noted that the Bunte Serie is unique in the Greek territory, outcropping only in Chios and the nearby Turkish peninsula of Karaburun. From a tectonic point of view, the thrust of the Parautochthonous unit on the Autochthonous corresponds to a thrust between the formations of the Autochthonous unit that was affected by shearing movements at the base of the Mesozoic.

In conclusion, the Autochthonous unit is presented under three different forms, in Chios: i) as an undisturbed sequence, ii) with a thrust structure between the massive limestones of the Mesozoic series (Upper Triassic) and the base of the Mesozoic and iii) with a thrust structure between the massive limestones of the Mesozoic and the Palaeozoic, as observed in the north-eastern part of the island. Although chronostratigraphic data could not easily be found in Chios, further research is needed for the interpretation of the complicated geological structure of this island, holding a key geodynamic position in the western Palaeotethys.

\section{References}

Besenecker, H., Durr, S., Herget, G., Jacobshagen, V., Kauffman, G., Ludtke, G., Roth, W. and Tietze, K.V., 1968. Geologie von Chios (Agais). Geol. Palaeontol., 2, 121-150.

Besenecker, H., Durr, S., Herget, G., Kauffman, G., Ludtke, G., Roth, W. and Tietze, K., 1971. Geological map of Greece. Chios, 1:50 000. IGME ed., Athens.

Herget, G., 1978. Die Geology von Nord-chios (Agais).Unpublished Ph.D. Thesis, Univ. of Marbrug.

Gaetani, M., Jacobschagen, V., Nicora, A., Kauffmann, G., Tselepides, V., Fantini-Sentini, N., Mertmann, D and Skourtis-Coroneou, V., 1992. The Early-Middle Triassic Boundary st Chios (Greece). Riv. Ital. 
Paleontol. Stratigraf., 98, 181-204.

Grooves, J., Larghi, C., Nicora, A., Rettori, R., 2003. Mississipian (Lower Carboniferous) microfossils from the Chios Melange (Chios island, Greece). Geobios, 36, 379-389.

Kauffmann, G., 1969. Die Geology von Nord-chios (Agais).Unpublished Ph.D. Thesis, Univ. of Marbrug.

Ktenas, K., 1921. Sur la decouverte du devonien a l'ile de Chio (Mer Egee). C.R.somm. Soc. Geol. France, 170-172.

Papanikolaou, D., Sideris, C.H., 1983. Le Palaeozoique de l'autochtone de Chios: une formation a blocks de type wildflysch d' age Permien. C.R.A.Sc., 297, 603-606.

Robertson, A., Pickett, E., 2000. Palaeozoic-early Tertiary evolution of melanges, rift and passive margin units in the Karaburun peninsula (western Turley) and Chios island (Greece). In tectonics and Magmatism in Turkey and the Surrounding area. Geological Society of London, Special publication, 173, 43-82.

Roth, G., 1968. Die Geology von Nord-chios (Agais).Unpublished Ph.D. Thesis, Univ. of Marbrug.

Tselepidis, V., 2007. Palaeontological and stratigraphic study of the Epidavros ammonites. Contribution to the knowledge of the "Hallstatt" facies in the Hellenides. Ph.D. Theseis, University of Thessaloniki (in Greek)

Zachi, A., Garzanti, E., Larghi, C., Angiolini, L. and Gaetani, M., 2003. The Variscan orogeny in Chios (Greece): Carboniferous accretion along a Palaeotethyan active margin. Terra Nova, 15/3, 213-223. 